\title{
PENERAPAN PENDIDIKAN DASAR MILITER (DIKSARMIL) DALAM MEMBENTUK KEPRIBADIAN RESIMEN MAHASISWA INSTITUT AGAMA ISLAM NEGERI (IAIN) PALU
}

\author{
Oyan D. Taufiq K. \\ oyan@iainpalu.ac.id \\ Dosen Institut Agama Islam Negeri (IAIN) Palu \\ Hairuddin Cikka \\ Dosen Fakultas Ushuluddin Adab dan Dakwah Institut Agama Islam Negeri (IAIN) Palu \\ hairuddincikka@iainpalu.ac.id
}

\section{Abstract}

The application of basic education in shaping the mentality and personality of the student regiment at IAIN Palu so that it can shape the mental and personality of the menwa members at IAIN Palu. The inhibiting factors in the process of applying basic education in boosting the mental and personality of the menwa in IAIN Palu are the equipment for training activities, the quantity of menwa in IAIN Palu, and the members of the menwa having difficulty spending time. Supporting factors are the support of the institute, the Central Sulawesi Menwa Commander, and the support of the Menwa alumni.

The implementation of basic education in shaping mental and personality is the manifestation of the character of Cinta Tanah Air in the Student Regiment of the State Islamic Institute of Palu (IAIN) Palu which is carried out through education, coaching, and activities, in the implementation of basic education in shaping mental and personality in the Student Regiment of the Institute of Religion Islamic State (IAIN) Palu for Guides and Senior Student Regiments should be more active, and need to be regulated in a specific regulation, to be more clear and detailed.

Key words: military basic education, personality student regiment

\footnotetext{
Abstrak

Penerapan pendidikan dasar dalam membentuk mental dan kepribadian resimen mahasiswa di IAIN Palu sehingga bisa membentuk mental serta kepribadian anggota menwa di IAIN Palu. Adapun faktor penghambat
} 
proses penerapan pendidikan dasar dalam membentul mental dan kepribadian menwa di IAIN Palu ialah perlengkapan kegiatan latihan, kuantitas menwa di IAIN Palu, serta anggota menwa sulit membagi waktu. Faktor pendukungnya ialah dukungan dari institut, komandan menwa sulawesi tengah, serta dukungan dari alumni menwa.

Pelaksanaan pendidikan dasar dalam membentuk mental dan kepribadian adalah wujud karakter Cinta Tanah Air pada Resimen Mahasiswa Institut Agama Islam Negeri (IAIN) Palu yang dilaksanakan melalui pendidikan, pembinaan, dan kegiatan, Dalam pelaksanaan penerapan pendidikan dasar dalam membentuk mental dan kepribadian pada Resimen Mahasiswa Institut Agama Islam Negeri (IAIN) Palu bagi Pembina dan para Senior Resimen Mahasiswa hendaknya lebih aktif, serta perlu diatur dalam suatu peraturan khusus, agar lebih jelas dan terperinci.

Kata Kunci: Penerapan Pendidikan Dasar Militer, kepribadian Resimen Mahasiswa

\section{Pendahuluan}

Resimen Mahasiswa (Menwa) adalah Rakyat Terlatih yang merupakan salah satu perwujudan keikutsertaan Mahasiswa dalam bela negara. Mahasiswa Indonesia sebagai generasi muda merupakan potensi nasional yang memiliki jumlah yang cukup besar dan sudah terorganisir dalam perguruan tinggi, oleh karena itu lebih mudah untuk mendidik dan melatih Mahasiswa menjadi Ratih dan juga mampu melaksanakan Perlindungan Masyarakat (Linmas). Dari berbagai macam Unit Kegiatan Mahasiswa (UKM) di kampus, maka Menwa termasuk dalam Unit Kegiatan Mahasiswa (UKM) khusus, yang pembinaannya oleh Pimpinan Perguruan Tinggi dan di luar Perguruan Tinggi oleh Komandan Resimen Mahasiswa.

Keanggotaan Resimen Mahasiswa dilaksanakan dengan kesukarelaan dan bagi yang memenuhi syarat serta diterima wajib mengikuti pendidikan dan pelatihan dasar. Pendidikan disini yang dimaksudkan adalah pendidikan bagi setiap anggota Resimen Mahasiswa yang merupakan syarat mutlak untuk menumbuhkan dan meningkatkan kemampuan Resimen Mahasiswa, yang terdiri atas :

a. Pendidikan Dasar Resimen Mahasiswa 
b. Kursus Kader Pelaksana Resimen Mahasiswa,

c. Kursus Kader Pimpinan Resimen Mahasiswa

Pendidikan Dasar adalah pendidikan dasar Resimen Mahasiswa yang harus diikuti bagi Mahasiswa yang lulus seleksi untuk menjadi anggota Resimen Mahasiswa. Pendidikan Dasar Resimen Mahasiswa (Diksar Menwa) bertujuan membentuk pribadi yang memiliki sikap, disiplin, mental, kemampuan fisik, pengetahuan dan keterampilan dasar, sebagaimana yang dipersyaratkan agar mampu melaksanakan tugas dan fungsi Resimen Mahasiswa sesuai dengan Panca Dharma Satya Resimen Mahasiswa. ${ }^{1}$

Kursus Kader Pelaksana Resimen Mahasiswa (Suskalak Menwa) adalah pendidikan lanjutan bagi anggota Resimen Mahasiswa yang memEnuhi persyaratan dan terpilih untuk menjadi Kader Pelaksana Resimen Mahasiswa. Suskalak Menwa bertujuan membentuk Kader Pelaksana Resimen Mahasiswa yang memiliki sikap, disiplin, mental, pengetahuan dan keterampilan menajemen, kemampuan fisik sebagaimana yang dipersyaratkan dan memiliki kemampuan melaksanakan fungsi Linmas. Kursus Kader Pimpinan Resimen Mahasiswa (Suskapin) adalah pendidikan lanjutan bagi Kader Pimpinan Resimen Mahasiswa dengan tujuan membentuk kader pimpinan dengan sikap, disiplin, mental, pengetahuan dan keterampilan kepemimpinan serta kemampuan fisik sebagaimana yang dipersyaratkan, dan memiliki kemampuan memimpin kegiatan baik yang bersifat intern maupun ekstern satuan.

Pelatihan Resimen Mahasiswa adalah segala kegiatan untuk menanamkan, menumbuhkan, meningkatkan dan memelihara keterampilan Personel Resimen Mahasiswa. Adapun latihan-latihan tersebut terdiri atas :

a. Pelatihan Pemeliharaan atau penyegara

b. Pelatihan Kepemimpinan Resimen Mahasiswa,

c. Pelatihan Terpadu.

Dengan menjadi seorang resimen mahasiswa, maka siapapun itu akan memiliki suatu pandangan hidup yang baru mengenai kedisiplinan, etika, sopan santun, hormat- 
menghormati, serta menjadi manusia Indonesia yang lebih berguna bagi Negara Kesatuan Republik Indonesia.

Secara umum sasaran pembinaan menwa di arahkan pada:

1. Terwujudnya Menwa sebagsai patriot pejuang, pelopor dalam pembangunan sebagai insan Pancasila yang bertakwa kepada Tuhan Yang Maha Esa.

2. Terwujudnya identitas Menwa sebagai Resimen Mahasiswa Indonesia yang terlatih dan sadar akan tanggung jawabnya dalam pembangunan negara serta menjunjung tinggi Tri Dharma Perguruan Tinggi selain sebagai komponen kekuatan Hankam.

3. Terwujudnya penghayatan, penyerapan serta pelaksanaan tekad dan pendirian Menwa Indonesia sebagai sumpah setia terhadap Pancasila dan UUD $1945 .^{2}$

Dalam wacana kemahasiswaan, mereka dibawah Mendikbud, karena sematamata mereka adalah mahasiswa Indonesia, dan juga mahasiswa Indonesia lainnya yang memiliki status mahasiswa. Unsur pembinaan dari Menhankam, karena secara atributif dan posisi mahasiswa dibekali dengan teori-teori dan praktik ketentaraan dan kesatrian yang seperti yang dicontohkan untuk militer kita, dan berkaitan dengan Depdagri, karena walau bagaimanapun, sebagai salah satu bentuk dari unsur bela negara, maka dia ditempatkan di bawah koordinasi Pertahanan sipil, yakni Mawil hansip. Jadi memang secara struktural pula, menwa adalah pertahanan sipil.

Ini pula yang menjadi pemicu tuduhan bahwa menwa dalam performansinya lebih mirip tentara dari pada sebagai sosok mahasiswa. Ini terlihat dari atribut yang dikenakan, dari cara berjalan, dan secara psikologis jiwa sesama korps lebih kuat karena mereka digodok di kawah Pendidikan dan Latihan Dasar Militer (DIKLATSARMIL) untuk beberapa minggu. Sejak awal mereka diposisikan sebagai pengamanan dalam kampus yang harus berhadapan dengan gerakan - gerakan mahasiswa yang semakin terdesak ke dalam kampus. Saat itu lazim terdengar ejekan kepada menwa sebagai "alat penguasa”. Kerana sejak akhir 1970-an, mereka cenderung diminorkan oleh mahasiswa

\footnotetext{
${ }^{2}$ http:/ / korsa-mahasurya.blogspot.com/2013/01/sejarah-resimen-mahasiswa-indonesia.html(on line) diakses pada tanggal 19 Oktober 2013.
} 
relatif menyusut, sumber perselisihan antar menwa dengan non-menwa berlangsung pada wilayah ini. Karena, terkadang persoalan sepele dan perbedaan penafsiran tentang kedisiplinan misalnya menwa ditempatkan sebagai penjaga kepentingan dan pimpinan perguruan tinggi setiap kali terjadi konflik dengan mahasiswa yang lain. ${ }^{3}$

Resimen Mahasiswa (MENWA) sebagai salah satu organisasi kemahasiswaan di perguruan tinggi merupakan wadah partisipasi mahasiswa dalam usaha bela negara Sebagai perwujudan pelaksanaan hak dan kewajiban setiap warga negara republik Indonesia dalam pertahanan negara dan sebagai tradisi semangat perjuangan dan pengabdian tanpa pamrih dari generasi tentara pelajar/korps mahasiswa. Sebagai realisasi sistem partahanan dan keamanan rakyat semesta dikalangan mahasiswa, adalah suatu kehormatan bagi setiap anggota menwa untuk melakukan pembelaan negara. Menwa adalah resimen pendidikan sesuai Tri Dharma perguruan tinggi untuk melahirkan sarjana-sarjana yang berwatak kesatria dan penuh dedikasi. ${ }^{4}$

Di kampus, keberadaan menwa cenderung kurang diminati dan mendapat sorotan oleh masyarakat kampus. Hal ini dikarenakan kurangnya pemahaman dan pengetahuan mahasiswa akan arti menwa itu sendiri khususnya di IAIN Palu. Dalam lingkup kampus, keberadaan menwa menempati posisi strategis sebagai mediator dan perwakilan masyarakat yang berkesempatan duduk di bangku kuliah. Maka, selayaknya keberadaan sebagai wakil ini memiliki prioritas yang baik untuk mendapatkan wawasan dan pengetahuan yang luas. Oleh sebab itu, bagi anggota menwa yang telah mengikuti pendidikan dasar (DIKSAR) maka anggota menwa tersebut telah diakui baik di kampus maupun di tingkat pusat provinsi.

Dengan penerapan pendidikan dasar menwa dalam membentuk mental dan kepribadian menwa di Institut Agama Islam Negeri (IAIN) Palu sehingga bisa menjadikan anggota menwa memiliki mental yang kuat dan kepribadian yang tidak mudah di pengaruhi kerena telah tertanam dalam diri anggota menwa "WIDYA

\footnotetext{
${ }^{3}$ http://korsa-mahasurya.blogspot.com/2013/01/sejarah-resimen-mahasiswa -indonesia.html diakses pada Tanggal 25 Oktober 2013.

${ }^{4}$ http://menwaunigal.wordpress.com/pendidikan-dasar-menwa-indonesia (on line) di akses pada Tanggal 28 oktober 2013.
} 
CASTREN A DHARMA SIDHA" yang artinya penyempurnaan ilmu pengetahuan dan ilmu olah keprajuritan. Dengan demikian pendidikan mengarahkan pada tujuan terwujudnya manusia yang seutuhnya. Sedangkan ilmu pengetahuan objeknya adalah peristiwa sosial maupun peristiwa alam. Titik berat ilmu pengetahuan adalah pemikiran tentang hubungan sebab akibat. Orang yang berilmu, tetapi kurang memahami soal pendidikan cenderung dapat menyalah gunakan ilmunya untuk berbagai kepentingan, baik yang positif maupun yang negatif. Sedangkan pendidikan mengarahkan manusia kepada perbuatan yang sesuai dengan nilai-nilai kemanusiaan. Jika dapat disimpulkan pendidikan dapat berfungsi sebagai mengawal ilmu pengetahuan menuju kearah yang manusiawi. Sedangkan pelatihan merupakan upaya melatih peserta didik agar apa yang dididikannya dapat tercapai. Jadi pelatihan hanyalah merupakan cara, dalam hal ini cara yang paling dasar (basic training), sedangkan pendidikan merupakan bagian utama yang dibicarakan. $^{5}$

Dalam hal ini juga mengindikasikan pendidikan merupakan suatu proses yang diperlukan manusia dalam menghadapi persoalan hidup. Manusia memiliki jiwa dan raga, sehingga yang perlu dididik itu adalah jiwa dan raganya. Pendidikan jiwa akan menghasilkan kemampuan intelektual, spritual, emosional, sedangkan pendidikan raga akan menghasilkan ketrampilan motorik, misalnya kemampuan menembak, kemampuan bela diri dan lain-lain. Pada intinya pendidikan dasar menwa merupakan suatu proses yang menghasilkan kesadaran dalam melihat persoalan kehidupan dan membentuk mental dan kepribadian serta kemampuan intelektual, spritual, emosional, sikap serta kecakapan dan ketrampilan (ketrampilan motorik), yang didasarkan pada nilai-nilai kemanusiaan, atas dasar itu manusia dapat mengatasi persoalan yang dihadapi dalam kehidupannya yang luhur. Dengan demikian pendidikan menyangkut perilaku manusia menuju cita-cita yang luhur. ${ }^{6}$

Bila ingin dikaitkan dengan menwa, maka pendidikan dasar menwa harus menghasilkan kemampuan pengetahuan dan ketrampilan dalam membentuk mental dan

${ }_{5}^{5}$ Direktorat Jenderal Potensi Pertahanan-Departemen Pertahanan, Tataran Dasar Bela Negara, (Jakarta: KEMHAN RI, 2006), 37.

${ }^{6} \mathrm{Ibid}, 62$. 
kepribadian yang berkaitan dengan bela negara. Jadi pendidikan dasar menwa adalah upaya untuk meningkatkan kemampuan intelektual, spiritual dan emosional, sikap dan ketrampilan dalam membentuk mental dan kepribadian menwa khususnya menwa IAIN Palu yang dilandasi dengan nilai-nilai kemanusiaan.

Dalam kehidupan sehari - hari, khususnya dalam hubungan interaksi sering ditemui berbagai macam permasalahan yang kadang - kadang tidak dapat diselesaikan hanya dengan satu cara, tetapi memerlukan berbagai macam cara yang terbaik. Contohnya seperti kita ketahui bersama bahwa masih banyak mahasiswa yang mengangap bahwa menwa itu adalah perpanjangan tangan dari aparat Tent.ara Nasional Indonesia (TNI) sehingga menwa diajarkan pula tentang Bela Diri Menwa (BDM) agar anggota menwa bisa menghadapi politik yang berada di dalam kampus khususnya dikampus IAIN Palu sehingga anggota menwa memiliki metal yang kuat dan kepribadian yang tak mudah digoyahkan oleh orang lain.

Pendidikan pada dasarnya merupakan bagian yang tidak terpisahkan dari kehidupan manusia. Dari mulai lahir (sejak dari buaian), manusia senantiasa belajar dengan yang terjadi di sekitarnya, hingga manusia lanjut usia bahkan meninggal dunia, ia tetap melakukan prakondisi dalam melihat persoalan yang dihadapi, dan inilah proses pembelajaran. Pandangan klasik tentang pendidikan pada umumnya dikatakan sebagai pranata yang dapat dijalankan pada tiga fungsi sekaligus;

Pertama, menyiapkan generasi muda untuk memegang peranan-peranan tertentu dalam masyarakat di masa depan. Kedua, mentransfer atau memindahkan pengetahuan, sesuai dengan peranan yang diharapkan, dan Ketiga, mentransfer nilai-nilai dalam rangka memelihara keutuhan dan kesatuan masyarakat sebagai prasyarat bagi kelangsungan hidup (survive) masyarakat dan peradaban. $^{7}$

Dalam hal ini pendidikan dasar juga merupakan keharusan bagi setiap manusia, Di era global sekarang ini, pendidikan merupakan sesuatu yang penting bagi semua orang

${ }^{7}$ Sutrisno, Dasar-Dasar Kependidikan militer (Jakarta: Ghalia Indonesia, 1996), 29. 
karena pendidikan merupakan akar dari peradaban sebuah bangsa. Pendidikan sekarang telah menjadi kebutuhan pokok yang harus dimiliki setiap orang agar dapat menjawab tantangan kehidupan dan ilmu pengetahuan.

Ilmu pengetahuan yang terbentuk pada peserta diksar dibangun oleh dirinya secara perlahan - lahan, kemudian diperluas melalui pengalaman dan pendidikan. Pengetahauan tidak dapat ditransfer oleh guru/pelatih kepada peserta diksar sacara acak tetapi tersistematis dan terarah. Pengetahuan bukan saja merupakan sekumpulan fakta, konsep atau kaidah yang siap untuk digunakan dan diingat, tetapi juga peserta diksar sendiri harus membangun pengetahuan itu sendiri dan memberi makna melalui pangalaman dalam kehidupan sehari - hari.

Dalam perkembangan selanjutnya, istilah pendidikan berarti bimbingan atau pertolongan yang diberikan secara baik kepada peserta diksar oleh seorang yang lebih dewasa agar peserta diksar menjadi dewasa atau mencapai tingkat kehidupan dan penghidupan yang lebih tinggi dalam arti mental dan kepribadiannya terbentuk. Dengan demikian segala usaha yang dilakukan oleh orang yang lebih dewasa dalam pergaulannya dengan peserta diksar untuk memimpin pekembangan jasmani dan rohaninya kearah yang lebih dewasa lagi

Pembentukan mental dan kepribadian menwa dimasa yang akan datang sangat besar pengaruhnya dari pengalaman yang diterima. Oleh karena itu, menwa harus mampu memberikan pengalaman untuk bisa menanamkan nilai - nilai pendidikan sehingga bisa membentuk mental dan kepribadian menwa di IAIN Palu yang sesuai dengan nilai - nilai pendidikan. Hal ini yang melatar belakangi mengapa pendidikan dasar menwa dianggap berpengaruh dalam membentuk mental dan kepribadian menwa di IAIN Palu.

Dalam menwa penerapan pendidikan dasar militer merupakan salah satu faktor yang mempengaruhi dalam proses pengakuan sebagai anggota menwa. Menwa merupakan suatu organisasi yang menerapkan pendidikan dasar militer terhadap anggota menwa yang baru saja bergabung di organisasi menwa sehingga mereka memiliki identitas yang sah baik menwa yang berada dikampus maupun yang berada di provinsi. 
Oleh karena itu, yang menjadi pokok permasalahan adalah "Bagaimana penerapan pendidikan dasar militer dalam meambentuk mental dan kepribadian menwa di IAIN Palu". Dari pokok permasalahan tersebut penulis mengemukakan sub permasalahan sebagai berikut :

1. Bagaimanakah Penerapan Pendidikan Dasar menwa dalam membentuk mental dan kepribadian menwa di IAIN Palu?

2. Apa Faktor Penghambat dan Pendukung Penerapan Pendidikan dasar dalam membentukan Mental dan Kepribadian pada Resimen Mahasiswa IAIN Palu?

\section{Pembahasan}

Pengertian Pendidikan dan Pendidikan Dasar Resimen Mahasiswa

1. Pengertian pendidikan.

Sebelum mengkaji lebih jauh tentang pendidikan, perlu dikemukakan terlebih dahulu apa itu Pendidikan. Dalam bahasa Indonesia, istilah pendidikan berasal dari kata "didik" dengan memberinya awal "pe" dan akhiran "an" yang mengandung arti "perbuatan (hal, cara dan sebagainya). Istilah pendidikan ini semula berasal dari bahasa Yunani, yaitu"paedagogie", yang berarti bimbingan yang diberi pada anak. Istilah ini kemudian deterjemahkan ke dalam bahsa inggris dengan "edication" yang berarti pengembangan atau bimbingan. Dalam bahasa arab istilah ini sering diterjemahkan dengan "tarbiyah" yang berarti pendidikan.

Dalam perkembangannya, pendidikan berarti usaha yang dijalani oleh seseorang atau sekelompok orang untuk memepengaruhi seseorang atau sekelompok orang agar menjadi dewasa atau mencapai tingkat hidup ada penghidupan yang lebih tinggi dalam arti mental. 
Pendidikan dapat diartikan secara sempit yaitu bimbingan yang diberikan kepada anak-anak sampai ia dewasa ${ }^{10}$. Sedangkan dalam arti luas adalah segala sesuatu yang menyangkut proses perkembangan dan pengembangan manusia, yaitu upaya menanamkan dan mengembangkan nilai-nilai bagi anak didik, sehingga nilai-nilai yang terkandung dalam pendidikan itu menjadi bagian dari kepribadian anak yang pandai, baik, mampu hidup, berguna bagi masyarakat ${ }^{11}$.

Definsi di atas mengandung pengertian yang lebih luas, yakni menyangkut perkembangan dan pengembangan manusia. Namun demikian, pengertian tersebut masih terbatas pada persoalan-persoalan duniawi. Dan belum memasukkan aspek spritual religius sebagai bagian terpenting yang mendasari pengembangan dan perkembangan manusia dalam proses pendidikan.

\section{Pendidikan dasar Resimen Mahasiswa}

Program Pendidikan Dasar menwa, sebagai salah satu pengembangan pendidikan lanjutan yang berada di resimen mahasiswa. Hal ini sangat bisa dipahami karena pendidikan dasar menwa merupakan salah satu sektor penentu keberhasilan pembangunan jiwa dan kepribadian serta mental resimen mahasiswa, baik dalam upaya peningkatan pemahaman tentang kepemimpinan lapangan, prosedur pimpinan pasukan, teknik penyelenggaraan latihan, tata upacara militer, ilmu medan peta dan kompas, pedoman administrasi umum menwa, perencanaan dan persiapan serta mempercepat pemahaman ilmu pengetahuan dan teknologi dalam rangka akselerasi kemajuan menwa, maupun dalam rangka mewujudkan cita-cita pembangunan nasional, yakni : "masyarakat adil dan makmur berdasarkan Pancasila dan UUD 1945".

Menyadari betapa besar peran pendidikan dasar menwa tersebut, kiranya sangatlah wajar jika seluruh anggota menwa Indonesia berkewajiban dan bertanggung jawab untuk turut serta menyukseskan Program Pendidikan Dasar menwa. Oleh karena itu, segala bentuk perhatian, partisipasi, dan pemikiran yang konstruktif dari semua pihak sangat diharapkan.

${ }^{10} \mathrm{Ibid}, 31$.

${ }^{11}$ M. Natsir Ali, Dasar-Dasar Ilmu Pendidikan (Jakarata: Mutiara, 1997), 23. 
Pendidikan dasar menwa juga dapat diartikan sebagai fundamental atau fondasi yang akan dibangun dalam diri setiap anggota menwa, apabila mendirikan suatu bangunan harus mempunyai landasan atau fondasi itu sendiri yang kokoh dan kuat. Untuk menentukakan kokoh atau kuatnya suatu bangunan tergantung dari kuatnya dasar atau fondasi itu sendiri. Oleh sebab itu, pendidikan dasar militer yang dibentuk menwa selalu kuat dan utuh sehingga tidak mudah digoyahkan oleh segala sesuatu,baik yang berupa ideologi yang muncul baik sekarang maupun yang akan datang. ${ }^{12}$

\section{Dasar, Tujuan, dan fungsi Pendidikan Dasar menwa}

\section{Dasar pelaksanaan pendidikan dasar menwa}

Segala aktivitas tertentu memiliki dasar atau landasan, demikian pula dalam hal pelaksanaan pendidikan dasar menwa landasan kerja dimaksudkan untuk dapat memberikan arah bagi pendidikan yang direncanakan. Sebab dengan adanya dasar berfungsi sebagai sumber peraturan yang akan diciptakan sebagai langkah pelaksanaan dan sebagai jalur untuk menentukan arah pendidikan dasar menwa tersebut.

Sebagimana telah diketuhui bahwa dasar dalam pelaksanaan pendidikan dasar menwa adalah Surat Keputusan Bersama (SKB) tiga menteri yaitu menteri pertahanan republik indonesia, menteri pendidikan dan kebudayaan, dan menteri dalam negeri dan otonomi daerah republik indonesia tahun 2000 tanggal 11 oktober 2000 tentang pembinaan dan pemberdayaan resimen mahasiswa. ${ }^{13}$

Dengan dasar tersebut sehingga Resimen Mahasiswa bisa selalu mengadakan pendidikan dasar menwa baik dilingkungan perguruan tinggi maupun di yang berada di Staf Komando Resimen Mahasiswa (SKOMEN). Oleh sebab itu, pendidikan dasar bagi Resimen Mahasiswa sangatlah penting dalam membentuk mental dan kepribadian setiap anggota resimen mahasiswa sehingga bisa memiliki:

1). Jiwa perjuangan bagi Resimen Mahasiswa.

2). Sikap displin, menta dan kepribadian yang kuat.

3). Kesehatan jasmani.

4). Pengetahuan dan keterampilan dasar bela negara. 2008), 34.

${ }^{12}$ Eko prasetyo, Menjadi Besar dan Terhormat dengan Pendidikan (Cet. II; Jakarta: Millenia Press,

13 Petunjuk pelaksana (Juklak) resimen mahasiswa, 17. 
5). Wawasan intelektual yang bisa diandalkan.

6).Jiwa kepemimpinan dan kemampuan manajemen agar Resime Mahasiswa dapat melaksanakan tugas dan fungsi sesuai dengan Panca Dharma Satya Resimen Mahasiswa. ${ }^{14}$

Ilmu pengetahuan yang didapatkan pada pendidikan dasar menwa inilah yang diterapkan pada kehidupan sehari - hari baik ia berada di kampus maupun di lingkungan masyarakat. Pada dasarnya pendidikan dasar menwa dilakukan untuk bisa mencari para mahasiswa yang ingin mengikuti pendidikan dasar resimen mahasiswa.

2. Tujuan pendidikan dasar menwa

Tujuan adalah suatu yang diharapkan tercapai setelah usaha atau kegiatan. Artinya tujuan merupakan kehendak seseorang untuk mendapatkan dan memiliki, serta memanfaatkan bagi kebutuhan dirinya sendiri atau untuk orang lain. ${ }^{15}$

Tujuan pendidikan dasar menwa adalah meletakkan dasar kecerdasan pengetahuan, kepribadian, akhlak mulia serta keterampilan untuk hidup mandiri dan mengikuti pendidikan dasar menwa lebih lanjut. Untuk mencapai tujuan pendidikan dasar resimen mahsiswa, dituntut peran seorang pelatih dalam proses membentuk mental dan kepribadian agar peserta pendidikan dasar menwa memiliki keseimbangan antara kognitif, afektif dan psikomotorik.

Tujuan Pendidikan dasar menwa adalah untuk terwujudnya anggota menwa yang beriman dan bertaqwa kepada kepada Tuhan Yang Maha Esa, berakhlak mulia, sehat, cerdas, berperasaan, berkemauan, dan mampu berkarya, mampu memenuhi kebutuhannya secara wajar, mampu mengendalikan hawa nafsunya, berkepribadian, bermasyarakat dan berbudaya.

\section{Fungsi Pendidikan Dasar Menwa}

Fungsi Pendidikan dasar menwa adalah untuk mewujudkan/mengembangkan berbagai potensi yang ada pada peserta pendidikan dasar menwa dalam konteks dimensi

\footnotetext{
${ }^{14}$ Ibid, 14.

${ }^{15}$ Susilowati, Patriotisme, 30.
} 
kehidupan keberagamaan, moralitas, individualitas/personalitas, sosialitas, dan kebudayaan secara menyeluruh dan terintegrasi. ${ }^{16}$

Fungsi Pendidikan Dasar menwa adalah :

1. Sebagai jenjang pendidikan awal dalam hubungannya dengan jenjang pendidikan selanjutnya yang ada di menwa.

2. Untuk mewujudkan/mengembangkan berbagai potensi yang ada pada peserta pendidikan dasar menwa dalam konteks dimensi kehidupan keberagamaan, moralitas, individualitas/personalitas, sosialitas, dan keberbudayaan secara menyeluruh dan terintegrasi, sehingga memiliki kemampuan dan keterampilan dasar untuk pendidikan selanjutnya dan bekal untuk hidup dalam masyarakat. ${ }^{17}$

\section{Metodologi Penelitian}

\section{A. Jenis penelitian}

Pendekatan merupakan asumsi yang mendasari dalam menggunakan pola pikir yang digunakan untuk membahas objek penelitian. Dalam penulisan karya ilmiah ini, penulis menggunakan metode pendekatan penelitian kualitatif deskriptif, yaitu memaparkan aspek - aspek yang menjadi sasaran penelitian penulis. Pendekatan yang dimaksud yaitu suatu penelitian yang berusaha untuk menuturkan pemecahan masalah yang ada sekarang berdasarkan data - data, sehingga penulis dapat menemukan kepastian dan keaslian data untuk diuraikan sebagai hasil penelitian yang akurat. Penelitian yang bersifat deskriptif menurut Suharmi Arikunto "lebih tetap apabila menggunakan pendekatan kualitatif'. ${ }^{18}$

\section{B. Lokasi penelitian}

Lokasi penelitian ini bertempat di Resimen Mahasiswa (MENWA) IAIN Palu. Pemilihan lokasi ini, sebagai penelitian antara lain kerena sangat mudah dijangkau sehingga timbul keingintahuan penulis terhadap penerapan pendidikan dasar (DIKSAR) dalam membentuk mental dan kepribadian resimen mahasiswa di IAIN Palu.

\section{Kehadiran peneliti}

16Rasminto, Setengah Abad Resimen Mahasiswa (Bandung : CV. Pustaka Setia, 1997), 53.

${ }^{17}$ Ibid, 55.

${ }^{18}$ SuharsimiArikunto, prosedur penelitian ilmiah, suatu pendekatan praktek,Ed.II, (cet. IX ; Jakarta : Rineka cipta, 1993), 209 
Dalam penelitian ini, kehadiran peneliti sebagai intrumen penelitian sekaligus sebagai pengumpulan data. Oleh karena itu, kehadiran penulis di lapangan untuk penelitian kualitatif sangat diperlukan sebagai pengamat penuh yang mengawasi kegiatan yang terjadi di Resimen Mahasiswa (MENWA) yang lebih terfokus pada penerapan pendidikan dasar (DIKSAR) dalam membentuk mental dan kepribadian Resimen Mahasiswa (MENWA) di IAIN Palu.

D. Data dan sumber data

Jenis data yang dikumpulkan oleh penulis terbagi dalam dua jenis, yaitu :

1. Data primer, yaitu jenis data lewat pengamatan langsung. Wawancara langsung dengan informan atau narasumber. Yang menjadi informan dalam penelitin ini meliputi komandan satuan, wakil komandan, senior, serta anggota Resimen Mahasiswa (MENWA) yang dipilih sebagai informan atau narasumber mewakili lainya.

2. Data sekunder, yaitu pengumpulan data melalui dokumentasi dan catatan yang berkaitan dengan objek penelitian, data sekunder dapat diperoleh berupa data, misalnya jumlah pelatih, siswa pendidikan dasar, sarana dan prasarana, serta informasi lainya yang dipandang berguna sebagai bahan pertimbangan analisis data primer.

\section{E. Teknik pengumpulan data}

Teknik pengumpulan data yang akan digunakan dalam penelitian ini adalah :

1. Observasi

Teknik observasi merupakan metode pengumpulan data dengan melakukan pangamatan terhadap objek yang diteliti dan pencatatan secara sistematik gajalayang di selidik. ${ }^{19}$

2. Interview (wawancara) adalah suatu metode yang dipergunakan penulis untuk melakukan wawancara terhadap informan dan responden yang telah ditetapkan sebelumnya. ${ }^{20}$

3. Dokumentasi

Dokumentasi merupakan pengumpulan dengan menelaah dokumen penting yang menunjang kelengkapan data. Dalam teknik pengummpulan data ini, penulis melakukan penelitian dengan meghimpun data yang relevan dari sejumlah dokumen resmi yang dapat menunjang kelengkapan dat penelitian

${ }^{19}$ S. Nasution, Metode Research Penelitian Ilmiah, (cet. VII : Jakarta : Bumi Aksara, 2004), 106.

${ }^{20}$ Ibid., 
dalam teknik dokumentasi ini, penulis juga memakai kamera untuk sebagai bukti bahwa penelitian ini benar dibukukan di lokasi yang dimaksud.

\section{F. Teknik Analisis Data}

1. Reduksi data

Reduksi data yaitu mereduksi data sehinggadapat disajikan dalam satu bentuk narasi yang utuh. ${ }^{21}$

2. Penyajian data

Penyajian data ialah menyajikan dat yang telah direduksi dalam model tertentu untuk menghindari adanya kesalahan penafsiran terhadap data tersebut. ${ }^{22}$

3. Verifikasi data

Verifikasi data yaitu pengambilan kesimpulan dari data yang didapatkan. ${ }^{23}$

\section{G. Pengecekan Keabsahan Data}

Sebagaimana dikemukakan oleh Lexi J. Moleong dalam buku "metodologi penilitian kualitatif' bahwa:

"Keabsahan data merupakan konsep penting yang diperbaharui dari konsep kesahihan (validitas) dan keandalan (reliabitas) menurut versi "positivisme" dan disesuaikan dengan tuntunan pengetahuan, kriteria dan paradigmanya sendiri. $^{24}$

\section{Hasil Penelitian}

\section{A. Gambaran Umum Tentang Menwa di LAIN Palu}

\section{Visi Menwa IAIN Palu}

Menyiapkan Mahasiswa sebagai generasi intelektual bangsa yang dibekali kemampuan dan pengetahuan dalam olah keprajuritan untuk pembelaan Negara serta berbagai keterampilan lain yang dimanfaatkan untuk masyarakat luas

${ }^{21}$ Matthew B. Milles, et.al, Qualitative Data Analisys, diterjemahkan oleh Tjetjep Rohendi Rohidi dengan judul analisis data qualitatif, buku sumber tentang metode baru, (cet. I ; Jakarta : UI-Press, 1992), 16.

${ }^{22}$ Ibid, 17.

${ }^{23}$ Ibid, 19.

${ }^{24}$ Ibid., 
menuju pengembangan bakat dan kepribadian individual secara penuh dan utuh. ${ }^{25}$

\section{Misi Menwa IAIN Palu}

1. Memberdayakan menwa menuju transformasi manusia dewasa yang kompeten, yang memiliki hati nurani dan yang mempunyai kepekaan untuk berani melibatkan diri pada hidup dan perjuangannya.

2. Menguatkan identitas kebangsaan terhadap Negara Kesatuan Republik Indonesia

3. Membentuk Mahasiswa yang memiliki mental dan kepribadian serta fisik yang tangguh, berdisiplin tinggi sebagai kader bangsa.

4. Melatih olah keperajuritan dalam rangka mempersiapkan potensi dalam bidang pertahanan Negara.

5. Menumbuhkan sifat teladan bagi seluruh individu anggota menwa dimanapun berada dalam upaya menciptakan kondisi lingkungan yang aman dan kondusif.

6. Membentuk dan mengasah kesigapan dan kewaspadaan terhadap perubahan yang dapat merugikan individu lain dalam skala luas. ${ }^{26}$

Resimen Mahasiswa adalah salah satu Unit Kegiatan Mahasiswa (UKM) di Institut Agama Islam Negeri (IAIN) Palu. Selain UKM Resimen Mahasisiswa, di IAIN Palu memiliki 7 UKM lain yang terbagi dalam beberapa bidang yaitu bidang Pencinta Alam, Kerohanian (Dakwah), Teater dan Seni, Anti Narkoba, Olahraga, dan Koperasi Mahasiswa Serta Pramuka. Kegiatan Resimen Mahasiswa ini termasuk dalam UKM Minat dan Kegemaran yang mewadahi minat dan bakat Mahasiswa dalam bidang Bela Negara, dimana peserta atau anggotanya berasal dari Mahasiswa aktif di lingkungan IAIN Palu.

\section{B. Pelaksanaan penerapan Pendidikan dasar dalam membentuk mental dan kepribadian anggota} Resimen Mahasiswa LAIN Palu.

a. Strategi/ Metode.

Strategi yang digunakan Menwa Menurut Salah satu anggota yang merupakan

${ }^{25}$ Dokumen Menwa di IAIN Palu, 2014.

${ }^{26}$ Dokumen Menwa di IAIN Palu, 2014. 
senior berpendidikan tertinggi di Resimen Mahasiswa yang baru saja mengikuti kursus kader pimpinan Menwa di Kopassus strategi yang harus digunakakan setiap anggota menwa yaitu,

'Keteladanan dari pembina dan senior Menwa. Pembina maupun Senior Menwa memberikan teladan dalam bentuk perilaku dan tindakan nyata dalam keseharian. Berpenampilan: ketika kuliah dan kegiatan baju harus disetrika rapi, sepatu harus disemir, potongan rambut pendek seperti TNI, baju harus dimasukan bagi yang putra, sedangkan yang putri bisa tidak harus dimasukan, yang terpenting adalah rapi.Berkomunikasi: Pembina maupun Senior memberikan suatu penghormatan dalam wujud peraturan penghormatan Menwa (PPM) bagi orang yang patut dihormati (Dosen, Menwa), hal tersebut merupakan bentuk sapaan/ salam dari Resimen Mahasiswa'. ${ }^{27}$

b. Nilai-nilai yang dikembangkan Menwa.

Nilai-nilai yang dikembangkan Menwa yaitu terutama sesuai dengan semboyan Widya Castrena Dharma Sidha yang berarti penyempurnaan ilmu pengetahuan dengan olah keprajuritan. Dalam aplikasinya nilai-nilai tersebut tercermin dalam berbagai kehidupan terutama sikap taqwa (religius), tanggap (peduli), tanggon ( menempatkan diri sesuai dengan tempatnya), toleransi dan demokratis, dan trengginas (cekatan) (tangguh).
c. Pembinaan, Pendidikan, dan Kegiatan Menwa IAIN Palu
1) Pembinaan.

Bentuk pembinaan yang digunakan pada Menwa adalah bentuk pembinaan sistem komando langsung. Hal ini sesuai dengan hasil wawancara dengan Kabiddiklat Menwa yang mengatakan bahwa:

"Pembinaan yang dilakukan di Menwa semuanya menggunakan sistem komando atau perintah langsung termasuk dari Menwa UNTAD, UNISA, UNISMUH, STIK IJ termasuk Menwa IAIN ini dimasing-masing Satuan dan dinaungi oleh Staf Komando Menwa (Skomen) Pawana Cakti yang merupakan induk yang menaungi Menwa yang ada disulawesi tengah dan Skomen Melaporkan segala kegiatan yang dilakukan didaerah kekantor pusat menwa

\footnotetext{
${ }^{27}$ Hairuddin Cikka, Kepala (Asisten Personil IV) Pengendalian Personil Staf Komando (Skomen) Pawana Cakti Sulteng, "Wawancara” tanggal 11 agustus, 2014
} 
dijakarta yaitu Komando Nasional Menwa (KONAS MENWA) yang merupakan pimpinan tertinggi Resimen mahasiswa Indonesia", 28

Berdasarkan penelitian ternyata bahwa, sistem yang digunakan oleh Resimen Mahasiswa adalah sistem komando semua UNTAD, UNISA, UNISMUH, STIK IJ, IAIN PALU baik Menwa yang ada di seluruh universitas yang ada Menwanya semuanya menggunakan sistem komando langsung .

2) Pendidikan

Pendidikan di Resimen Mahasiswa adalah suatu tahapan pendidikan yang harus dilalui oleh calon anggota sebelum menjadi anggota Resimen Mahasiswa dan untuk meningkatkan kapasitas serta kapabilitas sesuai dengan jenjang atau jabatannya. Jenjang pendidikan Resimen Mahasiswa meliputi: Pendidikan Dasar (Diksar), Kursus Kader Pelaksana (Suskalak), Kursus Kader Pimpinan (Suskapin), dan Pendidikan Khusus (Diksus). Dilihat dari berbagai sudut pandang sebagai berikut.

a) Pendidikan Dasar

Guna Pendidikan Dasar ini adalah syarat yang harus diikuti oleh mahasiswa yang telah lulus seleksi untuk menjadi anggota Resimen Mahasiswa. Pendidikan Dasar Resimen Mahasiswa bertujuan membentuk pribadi yang memiliki: jiwa kejuangan, sikap disiplin dan mental, kesemaptaan jasmani, pengetahuan dan keterampilan dasar Bela Negara, wawasan intelektual, jiwa kepemimpinan dan kemampuan manajerial, agar dapat melaksanakan tugas dan fungsi. ${ }^{29}$

Berdasarkan hasil penelitian di lapangan, Diksar Resimen Mahasiswa IAIN Palu periode 2014 ini baru akan dilaksanakan pada bulan Oktober tahun 2014 tepatnya di Depo Pendidikan (Dodik) Bela Negara Resimen Induk Daerah Militer (Rindam) VII/Wirabuana. Wawancara dengan Kaslan, Kepala Bidang Pendidikan dan Latihan Menwa IAIN, Tindak lanjut peneliti tentang wawancara dengan kepala bidang pendidikan dan latihan tentang pelaksanaan Diksar Resimen Mahasiswa IAIN dengan Menwa yang ada di Sulawesi tengah Bulan Oktober nanti di Depo Pendidikan

\footnotetext{
${ }^{28}$ Kaslan, Kepala Bidang pendidikan dan Latihan Menwa IAIN Palu, "Wawancara” Mako Menwa, tanggal 12 agustus, 2014

${ }^{29}$ Arfandi, Anggota Menwa IAIN Palu, “Wawancara”, Mako Menwa, tanggal 13 agustus, 2014
} 
(Dodik) Bela Negara Resimen Induk Daerah Militer (Rindam) VII/Wirabuana. Mengatakan bahwa jadwal Diksar Akan disusun berdasarkan Rapat dengan pengurus Menwa pawana cakti Sulteng. Selain itu Menurut Sekjen Ikatan Alumni Resimen Mahasiswa (IARMI) Menwa Sulawesi tengah, Hasil yang diperoleh dari materi pendidikan dasar adalah sebagai berikut.

(1) Kemenwaan.

Materi yang diperoleh pertama dalam pendidikan dasar di Depo Pendidikan (Dodik) Bela Negara Resimen Induk Daerah Militer (Rindam) VII/Wirabuana adalah Kemenwaan yang bertujuan penyaluran potensi dalam rangka mewujudkan hak dan kewajiban warga negara untuk ikut dalam usaha Bela Negara.

Hasil observasi lapangan, materi kemenwaan Resimen Mahasiswa sangat penting untuk materi pengenalan awal di Resimen Mahasiswa, materi kemenwaan ini adalah materi yang khas, karena hanya Resimen Mahasiswalah yang mendapatkan materi Kemenwaan ini. Bentuk materi kemenwaan berupa penyampaian materi didalam ruangan, pesertanya adalah anggota Resimen Mahasiswa IAIN pada khususnya, Pemateri diambilkan dari pemateri luar seperti dosen yang kopeten dalam bidang kemenwaan serta dari alumni Resimen Mahasiswa sendiri. Isi dari materi kemenwaan ini adalah sejarah tentang kemenwaan.

Pelaksanaan materi kemenwaan di Resimen Mahasiswa IAIN Palu diawali dari apel di dalam ruangan, yakni pemegang pasukan atau Danpok sebagai pemimpin apel, Danpok memimpin penghormatan kepada pemateri kemenwaan serta diikuti seluruh anggota Resimen Mahasiswa IAIN Palu, tidak hanya pemberian penghormatan tetapi juga menyanyikan lagu alumni atau pemateri siapa yang punya. Resimen Mahasiswa dalam menerima materi kemenwaan terlihat antusias dibuktikan dengan wujud pertanyaan-pertanyaan yang dilontarkan oleh Menwa kepada pemateri. Harapannya dengan pemberian penghormatan serta menyanyikan lagu alumni siapa yang punya, dapat meningkatkan semangat bela negara. ${ }^{30}$

\footnotetext{
30 Satar S. laupo, Sekretaris Jenderal Ikatan Alumni Resimen Mahasiswa (IARMI) pawana Cakti Sulawesi Tengah, "Wawancara”, Rumah Kediaman, tanggal 13 agustus, 2014.
} 
Hal tersebut juga diperkuat dari hasil wawancara dengan Wakil komandan Menwa, mengatakan bahwa:

"Izin memang dalam materi kemenwaan ini selalu diawali dengan pemberian penghormatan kepada pemateri yang biasa dipimpin oleh Danpok atau pemegang pasukan dimana Danpok memberikan instruksi penghormatan dalam ruangan dan menyanyikan lagu yang berjudul alumni siapa yang punya". ${ }^{11}$

Hal serupa juga diungkapkan oleh Mantan Komandan Satuan periode 2012 ketika wawancara mengatakan bahwa:

"Materi kemenwaan selalu diawali dari pemberian penghormatan di dalam ruangan atau apel di dalam ruangan, sudah menjadi tradisi di satuan 252 IAIN Palu ini, materi ini juga berisi tentang sejarah kemenwaan sehingga nantinya anggota Menwa mengerti dasar-dasar Resimen Mahasiswa". ${ }^{32}$

Dari uraian diatas dapat dikatakan bahwa pengembangan karakter Cinta Tanah Air Menwa dari materi kemenwaan, dilaksanakan melalui apel didalam ruangan, untuk membuka dan menutup materi serta menyanyikan lagu alumni siapa yang punya sehingga dapat meningkatkan semangat bela negaranya.

(2) Peraturan Baris Berbaris (PBB)

Materi yang kedua adalah PBB (Peraturan Baris-berbaris), dalam materi ini tujuannya adalah untuk membentuk disiplin setiap anggota Resimen Mahasiswa. Berdasarkan hasil peneliti di lapangan menunjukan bahwa, materi baris- berbaris atau (PBB) di Resimen Mahasiswa IAIN Palu adalah peserta PBB terdiri dari anggota Resimen Mahasiswa IAIN Palu pelatihnya biasanya diambilkan dari pelatih militer yakni TNI AD seperti yang diungkapkan oleh Kepala bidang Pendidikan dan latihan Bahwa,

"PBB itu adalah materi sebagai tolak ukur anggota dalam peraturan barisberbarisnya, kalau pematerinya tidak langsung dari TNI AD menurut saya kurang mantap. Materi PBB ini sangat menentukan bahwa anggota tersebut layak dikatakan sebagai anggota Resimen Mahasiswa IAIN Palu karena Menwa IAIN

\footnotetext{
${ }^{31}$ Novita R. Mardjun, Wakil Komandan Menwa IAIN Palu, "Wawancara”, Mako Menwa, tanggal 14 agustu, 2014

${ }^{32}$ Burhanuddin, Mantan Komandan satuan (Dansat) Menwa IAIN Palu 2012, "Wawancara", Mako Menwa, tanggal 14 agustus, 2014
} 
Palu terkenal gerakan tegas dari materi PBBnya."33

Hal tersebut senada yang diungkapkan oleh Novita ulfa salah satu anggota Menwa yang mengatakan bahwa,

"Saya sering mendapatkan sangsi berupa Pus-Up karena sering terlambat mengikuti kegiatan di Resimen Mahasiswa, karena harus jalan dari Kos ke Menwa lumayan membutuhkan waktu yang banyak, kalau tidak diterapkan dalam pelaksanaan kegiatan PBB ini saya tidak akan telat tidak hanya materi PBB saja penerapan Sanksi tetapi berlaku pada semua kegiatan yang ada di Resimen Mahasiswa IAIN Palu, walau seperti itu saya sadar tujuannya agar mental dan kepribadian saya bisa disiplin disegala bidang tidak hanya di materi PBB ini". ${ }^{34}$

(3)Kepemimpinan

Materi yang ke tiga ini adalah materi kepemimpinan. Tujuan dari materi kepemimpinnan untuk membentuk watak setiap anggota Resimen Mahasiswa agar memiliki jiwa pemimpin. Hasil dari peneliti dilapangan menunjukan bahwa, materi kepemimpinan pada Resimen Mahasiswa IAIN menggunakan sistem kepemimpinan semi militer. Hal tersebut juga senada yang diungkapkan Wakil komandan Menwa yang mengatakan bahwa:

"Kepemimpinan di Resimen Mahasiswa khususnya Menwa IAIN memang kami terapkan sesuai juklak TNI, kalau dalam TNI menggunakan sistem militer penuh, sedangkan pada Menwa IAIN Palu sendiri hanya sebagian atau dapat dikatakan semi militer" ${ }^{\prime 35}$

(4) Peraturan Penghormatan Militer (PPM)

Materi yang ke empat adalah materi Peraturan Penghormatan Militer (PPM) tujuannya agar Resimen Mahasiswa meningkatkan sikap saling menghormati dengan orang lain. Hasil penelitian dilapangan menunjukan bahwa, pelaksanaan materi PPM ini dilaksanakan dengan cara aplikasi lansung, anggota setiap mau berangkat ke kampus,

\footnotetext{
${ }^{33}$ Kaslan, Kepala Bidang pendidikan dan Latihan Menwa IAIN Palu, Mako Menwa, "Wawancara", tanggal 15 agustus, 2014

${ }^{34}$ Novita Ulfa, Kepala Bidang Keputrian Menwa IAIN Palu, Mako Menwa, "Wawancara”, tanggal tanggal 15 agustus , 2014

${ }^{35}$ Novita Ulfa, Kepala Bidang Keputrian Menwa IAIN Palu, "Wawancara”, Mako Menwa, tanggal 15 agustus , 2014
} 
setiap ketemu dengan senior, atau dosen pasti memberikan penghormatan atau PPM.

Hal serupa juga dikatakan oleh Komandan Satuan periode 2013 tanggal mengatakan bahwa

"Materi PPM ini adalah materi yang bisa langsung diaplikasikan setiap anggota Menwa karena disamping penghormatan adalah wajib diterapkan di lingkungan Menwa juga wajib diaplikasikan dalam penghormatan pada dosen jurusan, pejabat-pejabat IAIN Palu serta kepada orang yang pantas dihormati." ${ }^{36}$

b) Kursus kader pelaksana

Kursus Kader Pelaksana adalah Pendidikan lanjutan bagi anggota Resimen Mahasiswa yang memenuhi persyaratan dan terpilih untuk menjadi kader Pelaksana Resimen Mahasiswa. Kursus kader Pelaksana Resimen Mahasiswa bertujuan membentuk Kader Pelaksana yang memiliki sikap, kemampuan fisik, disiplin, mental, pengetahuan dan keterampilan manajemen serta kepemimpinan dan kemampuan melaksanakan fungsi Linmas.

"Berdasarkan hasil wawancara Kursus Kader Pelaksana Menwa selama periode dua tahun kebelakang yaitu tahun 2011 dan 2012 belum ada pendidikan Suskalak. Hal tersebut senada yang diungkapkan oleh Komandan satuan yang mengatakan bahwa: "suskalak ini adalah pendidikan lanjutan Menwa dan selama dua periode kebelakang tahun 2011 dan tahun 2012 sampai tahun 2013 memang belum ada tanda persiapan diadakannya Suskalak tersebut. ${ }^{37}$

c) Kursus kader pimpinan

Kursus Kader Kepemimpinan adalah pendidikan lanjutan bagi anggota Resimen Mahasiswa yang memenuhi persyaratan dan terpilih untuk menjadi kader pimpinan Resimen Mahasiswa, Kursus Kader Pimpinan Resimen Mahasiswa bertujuan membentuk Kader Pimpinan yang memiliki sikap, kemampuan fisik, disiplin, mental, pengetahuan dan keterampilan manajemen serta kepemimpinan

36 Burhanuddin, Komandan Satuan (Dansat) Menwa IAIN Palu 2013, "Wawancara”, Mako Menwa, tanggal 18 agustus, 2014

${ }^{37}$ Rizki Eko, Komandan Satuan Menwa IAIN Palu, “Wawancara”, Mako Menwa, tanggal 18 agustus, 2014 
dan kemampuan malaksanakan fungsi penanaman nilai-nilai Bela Negara, penguatan Ketahan Nasional dan pembangunan daerah. Kursus Kader Pimpinan guna mengisi jabatan-jabatan Komandan dan Kepala Staf Resimen Mahasiswa dan Komandan Batalyon Resimen Mahasiswa, Staf tingkat Asisten pada Staf Komando Resimen Mahasiswa, Pelatih Resimen Mahasiswa.

Berdasarkan hasil penelitian Kursus Kader Pimpinan Resimen Mahasiswa Institut Agama Islam Negeri (IAIN) terakhir tahun 2002 selama periode lima tahun kebelakang yaitu tahun 2003 sampai tahun 2012 belum ada pendidikan Suskapin. Nanti pada tahun 2013 Menwa Sulawesi Tangah mengirimkan kader terbaiknya 4 orang 1 dari UNTAD dan 1 dari STIK IJ dan IAIN Mengirimkan dua kader terbaiknya melalui seleksi dari tingkat daerah yang dilaksanakan oleh Staf Komando Menwa. ${ }^{38} \mathrm{Hal}$ tersebut senada yang diungkapkan oleh Komandan satuan yang mengatakan bahwa:

"Suskapin ini adalah pendidikan lanjutan khusus bagi calon pemimpin (Komandan), dan selama dua periode kebelakang tahun 2011 dan tahun 2012 dan nanti tahun 2013 ini baru dilaksakan pada bulan Mei dan Resimen Mahasiswa Institut Agama Islam Negeri (IAIN) Palu mengirimkan dua kader terbaiknya melalui seleksi yang dilaksanakan oleh Staf Komando Menwa Sulteng dan Resimen Mahasiswa Institut Agama Islam Negeri (IAIN) Palu yang terbanyak karena dari Untad dan STIK IJ masing-masing 1 Orang dan ini merupakan kebanggaan buat kami karena mereka dilatih oleh Grup 3 Kopassus salah satu Satuan Intelijen terelit didunia". 39

Berdasarkan hasil penelitian pada pendidikan di Resimen Mahasiswa yang meliputi pendidikan dasar, Suskalak dan Suskapin tidak dilaksanakan semua, seperti pendidikan suskapin dan suskalak, sedangkan hasil dari pendidikan yang sudah dilaksanakan adalah sudah sesuai dengan tujuan pendidikan membentuk mental dan kepribadian yang tangguh buat seluruh anggota Resimen Mahasiswa Institut Agama Islam Negeri (IAIN).

d) Kegiatan Lain di Resimen Mahasiswa Institut Agama Islam Negeri (IAIN) Palu.

\footnotetext{
${ }^{38}$ Hairuddin Cikka, Kepala (Asisten Personil IV) Pengendalian Personil Staf Komando (Skomen) Pawana Cakti Sulteng, "W awancara”, Mako Menwa, tanggal 20 agustus, 2014.

${ }^{39}$ Rizki Eko, Komandan Satuan Menwa IAIN Palu, Mako Menwa, "Wawancara", tanggal 20 agustus, 2014
} 
(1) Bela Diri Menwa.

Kegiatan jasmani terdiri dari Bela diri dapat berupa tarung derajat (boxer), pelaksanaannya 1 minggu sekali dalam setiap bulan, bergantung Satuan dan Universitas masing-masing. Hasil dari bela diri terbentuk sikap disiplin, pemberani dan kesatria yang tanggung jawab.

Hasil peneliti dilapangan menunjukan bahwa materi BDM diawalai dari apel mulai kegiatan, pemberian salam, dan latihan-latihan BDM. Anggotanya terlihat antusias dan senang dibuktikan dengan berbagai pertanyan yang dilontarkan pada pelatih tentang BDM ini.

Hal senada diungkapkan oleh Kabid Diklat Menwa yang mengatakan bahwa: "Materi BDM ini salah satu materi yang disukai anggota putra, tetapi dalam materi BDM ini setiap perlombaan malah anggota putri yang mempunyai kesempatan atau kopetisi lebih dibanding anggota putra set." ${ }^{, 40}$

Dari uraian diatas dapat dikatakan bahwa pengembangan Mental dan kepribadian Menwa dari materi BDM, diaplikasikan dan dibuktikan melalui sikap tanggap anggota dan keterampilan dalam gerakan BDM, sehingga harapannnya dari materi BDM ini anggota bisa mengasah keterampilan-keterampilannya dan juga berguna bagi orang lain nantinya.

(3) Kegiatan-kegiatan pendukung.

a. Do’a Bersama.

Hasil peneliti di lapangan menunjukan bahwa doa bersama dilaksanakan sebagai rutinitas anggota Menwa. Hal tersebut senada yang diungkapkan oleh Rudini yang mengatakan bahwa:

"Ya, doa bersama di Resimen Mahasiswa Institut Agama Islam Negeri (IAIN) memang sudah menjadi tradisi ataupun kegiatan satuan yang sifatnya rutinitas, tidak hanya dirumah kita melaksanakan doa bersama tetapi di Menwa pun juga bisa melaksanakan doa bersama" ${ }^{41}$

\footnotetext{
${ }^{40}$ Kaslan Raja, Kepala Bidang pendidikan dan Latihan Menwa IAIN Palu, "Wawancara”, Mako Menwa, tanggal 20 agustus, 2014.

${ }^{41}$ Rudini, Kepala Bidang Personalia Menwa IAIN Palu, "Wawancara”, Mako Menwa, tanggal 21 agustus, 2014.
} 
b. Bakti Sosial.

Kegiatan bakti sosial merupakan kegiatan pendukung Menwa diluar kegiatan rutinitas, kegiatan bakti sosial tujuannya untuk membentuk kepedulian antar sesama manusia sebagai ciptaan Tuhan dan sebagai hamba Tuhan yang diberikan kelebihan untuk saling tolong menolong. Hal tersebut senada yang diungkapkan oleh Komandan Satuan yang mengatakan bahwa:

"Dalam kegiatan bakti sosial Menwa tidak harus dalam bentuk kegiatan yang besar tatapi membersihkan lingkungan bersama dengan masyarakat setempat juga merupakan bakti sosial dan juga tidak menghilangkan makna dari kegiatan bakti sosial tersebut". ${ }^{4}$

c. Napak Tilas.

Kegiatan Perlombaan Napak tilas, kegiatan Lomba napak tilas Menwa SeIndonesia. Tujuan lomba napak tilas ini untuk meningkatkan jiwa nasionalisme. Menwa IAIN juga pernah mengadakan lomba Napak Tilas tepatnya tahun 2012. Hal tersebut senada yang diungkapkan oleh mantan Komandan 2012 yang mengatakan bahwa:

"Dulu Menwa IAIN pernah mengadakan lomba napak tilas, materi perlombaan terdiri dari seminar bela negara di gedung auditorium yang dulu belum semegah sekarang, pesertanya dari Menwa seluruh Indonesia, hadiah pertama memperebutkan piala bergilir, suasananya sangat ramai perlombaan juga terlaksana sesuai sportifitas dan itu merupakan kebanggaan karena merupakan kegiatan skala nasional yang pertama dilaksanakan di IAIN Palu."43

d. Lomba Lintas Medan.

Kegiatan Lomba Lintas Medan (LLM) tujuannya adalah untuk memupuk jiwa nasionalis dan Cinta Tanah Air terhadap bangsa. Hal ini sesuai hasil wawancara dengan peserta lomba lintas medan yang mengungkapkan:

"Lomba Lintas Medan tahun ini yang ke-4 sebagai agenda besar Satuan, namun belum terlaksana pesertanya juga dari seluruh Menwa Indonesia, menwa IAIN mengikuti pelaksanaannya tanggal 30 Mei 2012 lalu dimakasar namun tidak mendapat juara pada tahun 2014 Menwa IAIN kembali mengikuti

\footnotetext{
${ }^{42}$ Rizki Eko, Komandan Satuan Menwa IAIN Palu, "Wawancara”, Mako Menwa 252, tanggal 21 agustus, 2014

${ }^{43}$ Irfan Ismail, Mantan Komandan Menwa IAIN Palu 2012, "Wawancara", Mako Menwa, Tanggal 21 agustus, 2014
} 
kegiatan yang sama dan mendapat peringkat IV di UNHAS Makassar. ${ }^{44}$

e. Giat Kesbangpolinmas dan upacara hari besar.

Giat Kesbangpolinmas yang bertujuan untuk memperoleh pengetahuan Tugas pokok Linmas yang berkaitan dengan Menwa selaku mahasiswa misal pembinaan administrasi teknik dalam rangka kegiatan Satuan Menwa di Kampus berada di bawah pengendalian Departemen Pendidikan dan Kebudayaan (DEPDIKBUD). Upacaraupacara hari besar (hari kemerdekaan Repubilk Indonesia, hari juang Kartika TNI. Upacara hari-hari besar negara bertujuan untuk memupuk jiwa-jiwa nasionalisme Menwa.

Dari uraian diatas dapat dikatakan peneliti bahwa kegiatan di Menwa yang sudah dilaksankan yaitu beladiri, binjasmen, apel dan kegiatan pendukung (doa bersama, bakti sosial, perlombaan napak tilas, lomba lintas medan, giat kesbangpol, dan upacara-upacara hari besar). Semua kegiatan tersebut yang mendukung pelaksanaan pendidikan pengembangan mental dan kepribadian Menwa adalah terletak pada kegiatan-kegiatan pendukungnya yang meliputi: doa bersama, bakti sosial, perlombaan napak tilas, lomba lintas medan, giat kesbangpol, dan upacaraupacara hari besar).

C. Faktor-faktor Penghambat dan Pendukung Pelaksanaan Pendidikan dasar dalam Pembentukan Mental dan Kepribadian pada Resimen Mahasiswa LAIN Palu.

Faktor penghambat dari Internal.

1) Perlengkapan kegiatan latihan.

2) Kuantitas Menwa Iintitut Agama Islam Negeri (IAIN) Palu.

3) Anggota Menwa Kesulitan Membagi Waktu.

Faktor Pendukung dari eksternal.

1) Dukungan Universitas.

3) Dukungan Alumni. 
Solusi Mengatasi Faktor Penghambat

a. Memperbesar Anggaran Resimen Mahasiswa.

b. Setiap kegiatan pasti membutuhkan anggaran, seperti halnya di Menwa juga membutuhkan anggaran untuk kegiatan.

c. kelonggaran ijin bagi para Menwa baik dalam akademik maupun kegiatan Menwa.

d. Ijin mahasiswa adalah bukti kalau mahasiswa tersebut tidak bisa mengikuti suatu kegiatan, di Menwa IAIN juga sama memerlukan ijin untuk setiap melaksanakan kegiatan agar lancar.

e. Menanamkan jiwa kesatria, kejujuran dan keadilan.

Setiap manusia pasti bangga jika bisa menerapkan jiwa kesatria, kejujuran,

dan keadilan, karena menanamkan jiwa kesatria, kejujuran dan keadilan adalah suatu anugerah dan tidak semua orang bisa mengaplikasikannya.

\section{Daftar Pustaka}

Amin Maswardi Muhammad. Pendidikan Karakter Anak Bangsa. Jakarta: Baduose Media, 2011.

Susanto Budi, Gemerlap Nasionalitas Postkolonial. Yogyakarta: Kanisius, 2008.

Al-Attas al-Naquid Muhammad Syekh, Konsep Pendidikan Dalam Islam, (Bandung;Mizan,1984) cet. Ke-1.

Cholid Narbuku dan Abu Ahmad, Pengantar Metodologi Ilmiah, (Rineka Cipta 2004).

Departemn pendidikan dan kebudayaan RI, kamus besar bahasa indonesia, Ed I (Cet. II; Jakarta : Balai Pustaka).

Dewantara Ki Hajar, Bagian Pertama Pendidikan, (Yogyakarta; Majelis Luhur

Persatuan

Taman Siswa, 1962). Sebagaimana dikutip oleh Abuddin Nata

dalam

Kapita Selekta Pendidikan Islam,

Daryanto, Evaluasi Pendidikan, (Jakarta: Rineka Cipta, 2007)

Dasril, Pendidikan menwa dan ancaman perang, (Jakarta bina aksara: 2011),

Dedi Mulyana, Penelitian Kualitatif, (Cet. II; Bandung Remaja Rosdakarya, 
Eko prasetyo, Menjadi Besar dan Terhormat dengan Pendidikan, (Cet. II; Jakarta: Millenia Press, 2008)

Hasbullah, Dasar - dasar Pendidikan, (Cet. 10, Jakarta : Raja Grafindo persada, 2012).

Handoyo Handoyo, Eko dan Tijan. Model Pendidikan Karakter Berbasis Konservasi.

(Semarang: Cipta Prima Nusantara, 2010

Henry noer Aly dan H. Munzir sastra, watak pendidikan, (Jakarta : Friska Agung Insani, 2000).

http://menwaunigal.wordpress.com/sejarah-menwa-indonesia di akses pada tanggal 10 Desember 2013.

Headar Putra daulay, Pendidikan Islam Dalam Sistem Pendidikan Nasional Di Inadonesia (Jakarta: Kencana, 2006)

Ketetapan MPR-RI, No II, Garis-Garis Besar Haluan Negara (Jakarta: Penerbit Sinar Grafika, 1998)

Komando Nasional, Petunjuk teknis dan Petunjuk Latihan Menwa Indonesia. Jakarta, Konas Menwa, 2008.

Komando Nasional. Petunjuk Pelaksanaan Pembinaan Dan Pemberdayaan Resimen Mahasiswa Indonesia Dalam Bela Negara. Jakarta: Komando Nasional Resimen Mahasiswa Indonesia, 2007

Lexi J. Maleong, Analisis Data Kualitatif, (Cet. I; Jakarta: UI-Pres, 1992)

M. Ali Natsir, Dasar-dasar Ilmu Pendidikan, (Jakarta: Mutiara. 1997)

M. Noor syam, dienul islam penafsiran kembali islam sebagai suatu kaidah dan way of life (Cet. IV; Bandung : Al- Marif, 1981).

Matthew B. Milles, et.al, Qualitative Data Analisys, diterjemahkan oleh Tjetjep Rohendi Rohidi dengan judul analisis data qualitatif, buku sumber tentang metode baru, (cet. I ; Jakarta : UI-Press, 1992).

Nata Abuddin, Kapita Selekta Pendidikan, (Bandung;Angkasa, 2003)

Nur Uhbiyati, Ilmu pendidikan,(Bandung : CV. Pustaka Setia, 1997).

Poerwaadiminta, Kamus Umum Bahasa Idonesia (Jakarta: Balai Pustaka, 1976)

I wayan windia,. Meniti karir berbasis resimen mahasiswa, (bali antara: 2009) 
Madereni Iurnal Studi Ilmu Pengetahuan Sosial, Volume I, No. I, h. 110-139

Petunjuk pelaksana (Juklak) Resimen Mahasiswa.

Petunjuk tertulis (Juklis) Resimen Mahasiswa

Rayumis, Ilmu Pendidikan (Jakarta: Kalam Mulia, 2008)

SuharsimiArikunto, prosedur penelitian ilmiah, suatu pendekatan praktek,Ed.II, (Cet. IX ; Jakarta : Rineka cipta, 1993).

S. Nasution, Metode Research Penelitian Ilmiah, (cet. VII : Jakarta : Bumi Aksara, 2004).

Winarno Surakhmad, dasar - dasar dan teknik research pengantar metodologi ilmiah,Ed. VI, (Bandung, 1978).

Wahyuni susilowati, Patriotisme dan Dinamika Resimen Kampus, Nusa Cendikia. Bandung 2011. 